\title{
EDUCATION AND GENDER-BASED DIFFERENCES IN EMPLOYEE MOTIVATION
}

\author{
Miloš HITKA ${ }^{1^{*}}$, Ludmila KOZUBÍKOVÁ², Marek POTKÁNY 3 \\ 1, 3Department of Business Economics, Faculty of Wood Sciences and Technology, \\ Technical University in Zvolen, T. G. Masaryka 24, 960 53, Zvolen, Slovak Republic \\ ${ }^{2}$ Department of Enterprise Economics, Faculty of Management and Economics, \\ Tomas Bata University in Zlín, T. G. Masaryka 5555, 760 01, Zlín, Czech Republic
}

Received 03 July 2017; accepted 30 November 2017

\begin{abstract}
The main purpose of this article is to show dependencies between education and gender based on selected motivation factors. In order to obtain relevant data, the questionnaire method was used. In the years 2013-2016, 26,416 respondents participated. Descriptive statistics was used for data processing; the relationship between two categorical variables was verified by the chi-quadrate test and Tukey's HSD test. The results of the research proved the hypotheses; i.e. that there are significant differences in motivation factors among Slovak employees related to their gender and education. The most significant motivation factors included basic salary, job security and a good working team. The paper presents an original verifiable methodology that can be used in research of a similar focus in other European countries. The research results point to the potential of various alternatives for business managers responsible for preparing incentive motivation programmes related to the analysed factors.
\end{abstract}

Keywords: employee motivation, gender differences, education differences, motivation programme, quadratic chi-quadrate statistics, Slovakia.

JEL Classification: M12.

\section{Introduction}

This article presents an analysis and statistical evaluation of educational and gender differences in the employees' motivations. The authors have been conducting this survey for a long time, and its main purpose is to provide an information database to address the need to prepare different variants of motivational programmes from the point of view of analysed factors, from the point of view of the level of education and gender as well as from the perspective of the most preferred motivation factors among the employees.

${ }^{\star}$ Corresponding author. E-mail: hitka@tuzvo.sk

This is an Open Access article distributed under the terms of the Creative Commons Attribution License (http://creativecommons. org/licenses/by/4.0/), which permits unrestricted use, distribution, and reproduction in any medium, provided the original author and source are credited. 
One of the main tasks of a manager is to motivate employees in their organization to improve their work performance. The quality of the relationship between manager and employee is therefore one of the most powerful elements influencing performance and motivation (Fila et al. 2015; Chromjaková 2016). According to Kampf and Ližbetinová (2015), human sources became the most important and most expensive factor in manufacturing. Thus, human sources are the main assets to achieve the pre-set goals (Irum et al. 2012) of the company. Management of employees starts with the selection of a new employee and continues during his or her performance in the company (Stachová et al. 2015). Therefore, formation of a professional, positive and respectful relationship between employers and employees affects attitudes and satisfaction of employees (Lussier, Achua 2013).

The process of motivation itself is a process in which each person has certain needs that he or she seeks to satisfy and which influence his or her actions in a certain direction. This in turn leads to a certain response and the ultimate achievement of individual satisfaction. Most managers assume that financial evaluation is the most important factor in motivation, however, there are also many other motivation tools (including non-financial ones), for example job security, employee's recognition, further development in expertise, colleagues' recognition and many others (Hitka, Balážová 2015). However, managers should bear in mind that each employee is a specific person with special needs and requirements. Many attributes such as gender, age, education, duration of employment, and work category can significantly affect the level of motivation. Other motivation factors may include immediate staff needs and their immediate satisfaction. In the long run, employees' needs seldom considerably change, and therefore it is possible to define employee motivation needs based on research and then apply the research to their management.

\section{Differences in employees' motivation according to gender and education}

Work motivation is related not only to the employment sector, but also to other factors such as age, gender and education, especially at the management level. Eskildsen and Nussler (2003), for example, found out that high level of work motivation could lie on the fact that highly educated employees hold higher positions and receive more challenging tasks. Significant differences have also been identified between men and women (DeMartino, Barbata 2003).

Research of gender-related motivational differences is based on the idea of fundamental differences between men and women, i.e. on the existence of gender stereotypes. These stereotypes can be viewed within the historical context of male hegemony based on the gender differences in priorities and within qualitative differences between people. For example, according to Peterson (2004), men prefer self-employment and seek help from those in authority. On the other hand, women prefer to work interactively and seek help from colleagues with whom they are in working group. Current research shows that, although there are many similarities between male and female entrepreneurs, there are also several differences between them (Ryan, Deci 2000; Moran et al. 2001).

Buttner (1993) argues that women are influenced and motivated more by family needs, whereas men rate economic motives among their priorities. Further, women often start 
independent business career simply to avoid subdued position of an employee in their former workplace. Milne (2007) summed up the gender-related differences in entrepreneurial performance and motivation; the difference can be caused either by woman's social status that disadvantages and limits women, or by direct discrimination of women.

The feminist understanding of the reasons of discrimination of women at workplace also includes the fact that flexibility (related to her family) and the desire to create economic wealth are often women's motivation. These two aspects are, in Milne's view, linked to social feminism. However, studies of liberal and social feminism have come to a surprising conclusion that women have more substantial financial motivation factors (Arnania-Kepuladze 2010).

On the other hand, men long for independence, power and status, self-reliance and success (Sumita 2014). For men, there are more significant performance incentives such as financial income, freedom, promotion, challenge, and self-realization (Meece et al. 2006).

The level of education is another area which displays significant differences in employee motivation. Nadeem et al. (2011) state there are many variables that affect the level of motivation of university graduates. These include job responsibilities, working time requirements, low wages and various problems related to subordinates' behaviour.

Many of these items have a significant impact on the employee's attitude towards his or her work. However, education can differentiate the relationship between age and further education. It is likely that adults with a higher level of education are able to work independently and continuously develop (Warr, Birdi 1998).

According to Kanfer and Ackerman (2004), senior employees with higher education do not need to spend the same effort in their expertise to achieve the same performance as their younger colleagues with lower education.

Analysis of education-based motivation thus leads to a conclusion that male economic behaviour can be summarized by maxims such as promotion, recognition, success, tendency to earn money and work independently. Hitka and Balážová (2015) also assume that employees with higher education and higher numbers of years of work prefer other motivating factors than employees with lower education and fewer years of working performance. The authors analyse employees in terms of education, where the results show differences in the level of motivation. Similarly, Urbancová (2013) argues that undergraduates are motivated to succeed and strive to optimize their performance.

\section{Methodology}

The aim of this research is to find out if there are statistically significant differences in the motivation of employees of Slovak companies, depending on gender and education. To determine the level of motivation, we used a questionnaire method. The questionnaire consisted of closed questions. The first part of the questionnaire examined social, demographic and qualification characteristics of the employees in the companies that were selected to be the subject of research and comparison.

Through the questionnaire section basic data such as age, gender, seniority (number of years of work in the company), completed education and job position were gathered. The 
second part of the questionnaire was focused on the motivation factors. Via these, data such as characteristics of the work environment, working conditions, the system of assessment and remuneration in the company, the personnel work, the social care system and the employee benefits within the company were identified.

The survey was conducted in 2013-2016. The selection of respondents was proportionately allocated across Slovakia so that the research sample covered the country's entire area. The questionnaires were distributed among all areas of business and governmental institutions and attempted to cover a variety of entrepreneurial focuses, company sizes and genders, ages and education levels among their employees. We decided to exclude the temporal factor, as the analysed factors are currently not affected by the factor of time (Hitka et al. 2014).

Motivation factors were analysed in terms of:

- financial evaluation (basic salary, additional financial evaluation, fair employee evaluation);

- social security (social benefits, company vision, company name, region development, relationship to the environment, free time);

- job security (workplace security, job security, content and type of work done, familiarization with the achieved work result, working time, working environment, work performance, psychological burden);

- career advancement (ability to exercise own skills, work process, powers, prestige, self-decision, self-realization, education and personal growth, work recognition);

- interpersonal relationships (such as workplace atmosphere, working team, communication at workplace and superior's attitude) (Hitka, Balážová 2015).

In order to avoid negative interference of the respondents, individual motivation factors were alphabetically-ordered. Employees could assign each question to one of five levels of importance (according to the Likert scale; $5=$ maximum and $1=$ minimum).

The presented research methodology and its results are partial and verifiable in relation to further research, which currently includes the location of research in the aforementioned region as well as selected countries of Central and Eastern Europe.

Using the arithmetic mean of each motivation factor, we defined the order of importance of individual motivation factors. The relationship between two categorical variables in the context of inductive statistics was verified based on the chi-quadrate test (Pacáková et al. 2009).

Due to the selective nature of the data collected, the differences in the arithmetic mean of the importance of motivational factors for each employee at the level of significance $\alpha=$ $5 \%$ was tested by Tukey's HSD test. Tukey's HSD test is a single-step multiple comparison procedure. It is adapted for different numbers of observations in each group. It assumes independence between the levels of factors, variance of consistency, and normality. It can be used on raw data or in conjunction with an ANOVA (Post-hoc analysis) to find averages that are significantly different from each other.

On the basis of the acquired and theoretical data, we were able to set working hypotheses, which were consequently verified by the test characteristics of a square contingency. Following the table of standardized residuals (observed and expected) we state the most frequent occurrence of dependence. For categorical signs, where statistically significant dependence has been confirmed, a table of residual abilities was presented to determine where 
the dependence is most evident (Schmidtová, Vacek 2016). Consequently were formulated working hypotheses:

- WH1: We expect significant differences between employees with different levels of education in terms of motivation;

- WH2: We assume that there are significant differences between men and women in terms of motivation;

- WH3: We assume that base salary is significantly more important for men than for women, regardless of education;

- WH4: We assume that good working team is significantly more significant for women than for men, regardless of education;

- WH5: We assume that job security is significantly more significant for men than for women, regardless of education.

\section{Results (empirical findings)}

Questionnaires were distributed to companies both electronically and personally. In total, 26,416 respondents participated. Respondents were of various age, education, seniority and job positions. The characteristics of respondents are provided in Tables 1 and 2. We used the STATISTICA 12 software (StatSoft 2013) to evaluate obtained data.

Table 1. Number of respondents for each year

\begin{tabular}{|c|c|c|l|c|l|l|c|}
\hline \multicolumn{2}{|c|}{2013} & \multicolumn{2}{c|}{2014} & \multicolumn{2}{c|}{2015} & \multicolumn{2}{c|}{2016} \\
\hline \multicolumn{2}{|c|}{9,457} & \multicolumn{2}{c|}{8,045} & \multicolumn{2}{c|}{4,444} & \multicolumn{2}{c|}{4,470} \\
\hline male & female & male & female & male & female & male & female \\
\hline 4,677 & 4,780 & 4,368 & 3,677 & 2,207 & 2,237 & 2,411 & 2,059 \\
\hline
\end{tabular}

Table 2. Structure of sampling unit

\begin{tabular}{|l|c|c|c|l|c|}
\hline \multicolumn{2}{|c|}{ Gender } & \multicolumn{2}{c|}{ Age } & \multicolumn{2}{c|}{ Education } \\
\hline \multirow{2}{*}{ Male } & \multirow{2}{*}{13,663} & Up to 30 & 6,421 & Primary school & 689 \\
\cline { 3 - 6 } & & $31-40$ & 8,267 & Lower secondary education & 4,484 \\
\hline \multirow{2}{*}{ Female } & \multirow{2}{*}{12,753} & $41-50$ & 7,357 & Upper secondary education & 14,329 \\
\cline { 3 - 6 } & & $51+$ & 4,371 & Higher education & 6,914 \\
\hline
\end{tabular}

On the basis of the average values of importance, we selected three of the 30 most important motivational factors analysed for the purposes of the work. This is the basic salary as part of financial incentives, a good working team as part of motivation factors in the field of human relations and job security as part of social security motivation factors.

Table 3 lists the descriptive characteristics of the selection mean, the standard deviation, and the $95 \%$ confidence interval for the base file diameter. This means that, with a probability of $95 \%$, the respondents will evaluate the motivation factors listed at the level of the calculated average. 
Table 3. Descriptive statistic and confidence interval 95\%

\begin{tabular}{|l|c|c|c|c|}
\hline \multirow{2}{*}{ Motivation factor } & \multirow{2}{*}{ Average } & \multirow{2}{*}{$\begin{array}{c}\text { Standard } \\
\text { deviation }\end{array}$} & & \multicolumn{2}{c|}{ Confidence interval 95\% } \\
\cline { 4 - 5 } & & & Low limit & Top limit \\
\hline Base salary & 4.49 & 0.82 & 4.48 & 4.50 \\
\hline Good working team & 4.41 & 0.76 & 4.40 & 4.42 \\
\hline Job security & 4.40 & 0.82 & 4.39 & 4.41 \\
\hline
\end{tabular}

\subsection{Motivation factor: base salary}

Every employee deserves to be financially rewarded for his or her performance by salary. Salary reflects the cost of labour. It also takes into account physical and mental labour demand, necessary education and practice. Salary can also be a stimulus through which it affects employee's work performance. We found out that $89.59 \%$ of the respondents rated the basic salary as "very important" and "important" (Table 4). In the Likert scale, the aforementioned research result was considered in all levels of education as important (4) or very important (5).

Table 4. Relative frequency for motivational factor base salary from the point of view of education

\begin{tabular}{|l|c|c|c|c|c|c|}
\hline \multirow{2}{*}{ Education } & \multicolumn{5}{|c|}{ Values of importance } & \multirow{2}{*}{ Total } \\
\cline { 2 - 7 } & 1 & 2 & 3 & 4 & 5 & \\
\hline \multirow{2}{*}{ Primary school } & 19 & 21 & 68 & 174 & 407 & 689 \\
\cline { 2 - 7 } & $2.76 \%$ & $3.05 \%$ & $9.87 \%$ & $25.25 \%$ & $59.07 \%$ & $100 \%$ \\
\hline $\begin{array}{l}\text { Lower secondary } \\
\text { education }\end{array}$ & 90 & 123 & 367 & 1,060 & 2,844 & 4,484 \\
\cline { 2 - 7 } & $2.01 \%$ & $2.74 \%$ & $8.18 \%$ & $23.64 \%$ & $63.43 \%$ & $100 \%$ \\
\hline $\begin{array}{l}\text { Upper secondary } \\
\text { education }\end{array}$ & 161 & 275 & 993 & 3,550 & 9,350 & 14,329 \\
\cline { 2 - 7 } & $1.12 \%$ & $1.92 \%$ & $6.93 \%$ & $24.77 \%$ & $65.26 \%$ & $100 \%$ \\
\hline \multirow{2}{*}{ Higher education } & 64 & 110 & 457 & 1,903 & 4,380 & 6,914 \\
\cline { 2 - 7 } & $0.93 \%$ & $1.59 \%$ & $6.61 \%$ & $27.52 \%$ & $63.35 \%$ & $100 \%$ \\
\hline Total & 334 & 529 & 1,885 & 6,686 & 16,981 & 26,416 \\
\hline
\end{tabular}

Based on Pearson's chi-quadrate test, we confirmed that the level of education and motivation factor base salary are interdependent (p-level < 0.05) (Table 5). We thus confirm WH1 for the motivation factor base salary.

Table 5. $\chi^{2}$ test for motivational factor base salary from the point of view of education

\begin{tabular}{|l|c|c|c|}
\hline & Chi-square & Degree of freedom & $\mathrm{p}$-level \\
\hline Pearson's chi-square & 106.73 & $\mathrm{df}=12$ & $\mathrm{p}=0.000$ \\
\hline M-V chi-square & 98.85 & $\mathrm{df}=12$ & $\mathrm{p}=0.000$ \\
\hline
\end{tabular}

Based on Pearson's chi-quadrate test, we conclude (Table 6) that gender and motivation factor base salary are interdependent ( $\mathrm{p}$-level $<0.05)$. 
Table 6. $\chi^{2}$ test for motivational factor base salary from the point of view of gender

\begin{tabular}{|l|c|c|c|}
\hline & Chi-square & Degree of freedom & $\mathrm{p}$-level \\
\hline Pearson's chi-square & 21.30 & $\mathrm{df}=4$ & $\mathrm{p}=0.000$ \\
\hline M-V chi-square & 21.34 & $\mathrm{df}=4$ & $\mathrm{p}=0.000$ \\
\hline
\end{tabular}

Using the Tukey's HSD test, we rigorously tested the average values of gender-education relevance (Table 7). In the case of the motivation factor basic salary we would like to point out significant differences at a $5 \%$ level of significance between men with basic education and women with basic education, between men and women with GCSE (upper secondary education) and without GCSE (lower secondary education), and between male university graduates and women with primary education and high school education with and without GCSE. It seems that for men with basic education and men with university education, basic salary is a much more significant motivational factor than for women of any education level. Although financial incentives do not have long-term effectiveness, our findings give managers a tool to motivate employees in the form of additional financial benefits such as rewards and bonuses. The findings confirm WH3 partially. The base salary is very important for women with primary and higher education.

Table 7. Tukey's HSD test results within motivational factors for base salary

\begin{tabular}{|c|c|c|c|c|c|c|c|c|}
\hline $\begin{array}{l}\text { Gender/ } \\
\text { Education }\end{array}$ & $\begin{array}{l}\text { Male } \\
\text { pri- } \\
\text { mary } \\
\text { educa- } \\
\text { tion }\end{array}$ & $\begin{array}{l}\text { Male, } \\
\text { lower } \\
\text { second- } \\
\text { ary edu- } \\
\text { cation }\end{array}$ & $\begin{array}{l}\text { Male, } \\
\text { upper } \\
\text { second- } \\
\text { ary edu- } \\
\text { cation }\end{array}$ & $\begin{array}{l}\text { Male, } \\
\text { univer- } \\
\text { sity edu- } \\
\text { cation }\end{array}$ & $\begin{array}{c}\text { Female } \\
\text { primary } \\
\text { educa- } \\
\text { tion }\end{array}$ & $\begin{array}{l}\text { Female, } \\
\text { lower } \\
\text { second- } \\
\text { ary edu- } \\
\text { cation }\end{array}$ & $\begin{array}{l}\text { Female, } \\
\text { upper } \\
\text { second- } \\
\text { ary edu- } \\
\text { cation }\end{array}$ & $\begin{array}{c}\text { Female, } \\
\text { higher } \\
\text { educa- } \\
\text { tion }\end{array}$ \\
\hline $\begin{array}{l}\text { Male } \\
\text { primary } \\
\text { education }\end{array}$ & & 0.238 & 0.880 & 0.197 & 0.005 & 0.006 & 0.021 & 0.913 \\
\hline $\begin{array}{l}\text { Male, lower } \\
\text { secondary } \\
\text { education }\end{array}$ & 0.238 & & 0.991 & 0.184 & 0.715 & 0.826 & 0.947 & 0.225 \\
\hline $\begin{array}{l}\text { Male, up- } \\
\text { per second- } \\
\text { ary educa- } \\
\text { tion }\end{array}$ & 0.880 & 0.991 & & 0.513 & 0.280 & 0.817 & 0.492 & 0.551 \\
\hline $\begin{array}{l}\text { Male, uni- } \\
\text { versity edu- } \\
\text { cation }\end{array}$ & 0.197 & 0.184 & 0.513 & & 0.001 & 0.001 & 0.007 & 0.324 \\
\hline $\begin{array}{l}\text { Female } \\
\text { primary } \\
\text { education }\end{array}$ & 0.005 & 0.715 & 0.280 & 0.001 & & 1.000 & 0.299 & 0.688 \\
\hline $\begin{array}{l}\text { Female, } \\
\text { lower } \\
\text { secondary } \\
\text { education }\end{array}$ & 0.006 & 0.826 & 0.817 & 0.001 & 1.000 & & 0.584 & 0.991 \\
\hline
\end{tabular}


End of Table 7

\begin{tabular}{|l|c|c|c|c|c|c|c|c|}
\hline $\begin{array}{c}\text { Gender/ } \\
\text { Education }\end{array}$ & $\begin{array}{c}\text { Male } \\
\text { pri- } \\
\text { mary } \\
\text { educa- } \\
\text { tion }\end{array}$ & $\begin{array}{c}\text { Male, } \\
\text { lower } \\
\text { second- } \\
\text { ary edu- } \\
\text { cation }\end{array}$ & $\begin{array}{c}\text { Male, } \\
\text { upper } \\
\text { second- } \\
\text { ary edu- } \\
\text { cation }\end{array}$ & $\begin{array}{c}\text { Male, } \\
\text { univer- } \\
\text { sity edu- } \\
\text { cation }\end{array}$ & $\begin{array}{c}\text { Female } \\
\text { primary } \\
\text { educa- } \\
\text { tion }\end{array}$ & $\begin{array}{c}\text { Female, } \\
\text { lower } \\
\text { second- } \\
\text { ary edu- } \\
\text { cation }\end{array}$ & $\begin{array}{c}\text { Female, } \\
\text { upper } \\
\text { second- } \\
\text { ary edu- } \\
\text { cation }\end{array}$ & $\begin{array}{c}\text { Female, } \\
\text { higher } \\
\text { educa- } \\
\text { tion }\end{array}$ \\
\hline $\begin{array}{l}\text { Female, } \\
\text { upper } \\
\text { secondary } \\
\text { education }\end{array}$ & 0.021 & 0.947 & 0.492 & 0.007 & 0.299 & 0.584 & & 0.972 \\
\hline $\begin{array}{l}\text { Female, } \\
\text { higher edu- } \\
\text { cation }\end{array}$ & 0.913 & 0.225 & 0.551 & 0.324 & 0.688 & 0.991 & 0.972 & \\
\hline
\end{tabular}

Note: Significantly important values are highlighted in italic.

\subsection{Motivation factor: good working team}

Understanding among members of a working team is very important for the development of the company. It may also positively affect their work performance. Cooperation of employees brings a number of benefits, for example, they can advise each other and co-work. A good working team can also be a strong motivation-enhancing element. Sometimes a good working team can be even stronger motivation than financial motivation. We noted that as many as $89.37 \%$ of the respondents evaluate the motivation factor of a good working team as "very important" and "important" (Table 8).

Table 8. Relative frequency for motivational factor good working team from the point of view of education

\begin{tabular}{|l|c|c|c|c|c|c|}
\hline \multirow{2}{*}{$\begin{array}{c}\text { Level of } \\
\text { education }\end{array}$} & \multicolumn{5}{|c|}{ Values of importance } & \multirow{2}{*}{ Total } \\
\cline { 2 - 6 } & 1 & 2 & 3 & 4 & 5 & \\
\hline \multirow{2}{*}{$\begin{array}{l}\text { Primary } \\
\text { school }\end{array}$} & 14 & 33 & 96 & 256 & 290 & 689 \\
\cline { 2 - 6 } & $2.03 \%$ & $4.79 \%$ & $13.93 \%$ & $37.16 \%$ & $42.09 \%$ & $100 \%$ \\
\hline $\begin{array}{l}\text { Lower } \\
\text { secondary } \\
\text { education }\end{array}$ & 38 & 129 & 514 & 1,734 & 2,069 & 4,484 \\
\cline { 2 - 6 } & $0.85 \%$ & $2.88 \%$ & $11.46 \%$ & $38.67 \%$ & $46.14 \%$ & $100 \%$ \\
\hline $\begin{array}{l}\text { Upper } \\
\text { secondary } \\
\text { education }\end{array}$ & $6.46 \%$ & $1.50 \%$ & $7.84 \%$ & $35.14 \%$ & $55.06 \%$ & $100 \%$ \\
\cline { 2 - 6 } & 32 & 104 & 441 & 2,260 & 4,077 & 6,914 \\
\cline { 2 - 6 } $\begin{array}{l}\text { Higher } \\
\text { education }\end{array}$ & $0.46 \%$ & $1.50 \%$ & $6.38 \%$ & $32.69 \%$ & $58.97 \%$ & $100 \%$ \\
\hline Total & 150 & 481 & 2,175 & 9,285 & 14,325 & 26,416 \\
\hline
\end{tabular}


Table 9. $\chi^{2}$ test for motivational factor good working team from the point of view of education

\begin{tabular}{|l|c|c|c|}
\hline & Chi-square & Degree of freedom & $\mathrm{p}$-level \\
\hline Pearson's chi-square & 356.41 & $\mathrm{df}=12$ & $\mathrm{p}=0.000$ \\
\hline M-V chi-square & 326.56 & $\mathrm{df}=12$ & $\mathrm{p}=0.000$ \\
\hline
\end{tabular}

Based on Pearson's chi-quadrate test, we confirmed (Table 9) that the level of education and the motivation factor of a good working team are interdependent ( $\mathrm{p}$-level $<0.05$ ), thus confirming WH1 for the motivation factor good working team. Based on Pearson's chi-quadrate test, we can conclude (Table 10) that gender and motivation factor of a good working team are interdependent $(\mathrm{p}$-level $<0.05)$. Men considered good working team to be "important" whereas women considered it "very important", we thus confirm WH2 for the motivation factor of a good working team.

Table 10. $\chi^{2}$ test for motivational factor good working team from the point of view of gender

\begin{tabular}{|l|c|c|c|}
\hline & Chi-square & Degree of freedom & $\mathrm{p}$-level \\
\hline Pearson's chi-square & 108.72 & $\mathrm{df}=4$ & $\mathrm{p}=0.000$ \\
\hline M-V chi-square & 109.07 & $\mathrm{df}=4$ & $\mathrm{p}=0.000$ \\
\hline
\end{tabular}

Table 11. Tukey's HSD test results within motivational factors for good working team

\begin{tabular}{|c|c|c|c|c|c|c|c|c|}
\hline $\begin{array}{c}\text { Gender/ } \\
\text { Education }\end{array}$ & $\begin{array}{l}\text { Male } \\
\text { pri- } \\
\text { mary } \\
\text { educa- } \\
\text { tion }\end{array}$ & $\begin{array}{l}\text { Male, } \\
\text { lower } \\
\text { second- } \\
\text { ary edu- } \\
\text { cation }\end{array}$ & $\begin{array}{l}\text { Male, } \\
\text { upper } \\
\text { second- } \\
\text { ary edu- } \\
\text { cation }\end{array}$ & $\begin{array}{l}\text { Male, } \\
\text { univer- } \\
\text { sity edu- } \\
\text { cation }\end{array}$ & $\begin{array}{l}\text { Female } \\
\text { primary } \\
\text { educa- } \\
\text { tion }\end{array}$ & $\begin{array}{l}\text { Female, } \\
\text { lower } \\
\text { second- } \\
\text { ary edu- } \\
\text { cation }\end{array}$ & $\begin{array}{l}\text { Female, } \\
\text { upper } \\
\text { second- } \\
\text { ary edu- } \\
\text { cation }\end{array}$ & $\begin{array}{c}\text { Female, } \\
\text { higher } \\
\text { educa- } \\
\text { tion }\end{array}$ \\
\hline $\begin{array}{l}\text { Male } \\
\text { primary } \\
\text { education }\end{array}$ & & 0.521 & 0.089 & 0.587 & 0.058 & 0.000 & 0.000 & 0.009 \\
\hline $\begin{array}{l}\text { Male, lower } \\
\text { secondary } \\
\text { education }\end{array}$ & 0.521 & & 0.123 & 0.251 & 0.776 & 0.017 & 0.000 & 0.000 \\
\hline $\begin{array}{l}\text { Male, } \\
\text { upper } \\
\text { secondary } \\
\text { education }\end{array}$ & 0.089 & 0.123 & & 0.587 & 0.054 & 0.006 & 0.000 & 0.000 \\
\hline $\begin{array}{l}\text { Male, } \\
\text { university } \\
\text { education }\end{array}$ & 0.587 & 0.251 & 0.587 & & 0.624 & 0.000 & 0.000 & 0.950 \\
\hline $\begin{array}{l}\text { Female } \\
\text { primary } \\
\text { education }\end{array}$ & 0.058 & 0.776 & 0.054 & 0.624 & & 0.834 & 0.000 & 0.056 \\
\hline $\begin{array}{l}\text { Female, } \\
\text { lower } \\
\text { secondary } \\
\text { education }\end{array}$ & 0.000 & 0.017 & 0.006 & 0.000 & 0.834 & & 0.000 & 0.046 \\
\hline
\end{tabular}


End of Table 11

\begin{tabular}{|l|c|c|c|c|c|c|c|c|}
\hline $\begin{array}{c}\text { Gender/ } \\
\text { Education }\end{array}$ & $\begin{array}{c}\text { Male } \\
\text { pri- } \\
\text { mary } \\
\text { educa- } \\
\text { tion }\end{array}$ & $\begin{array}{c}\text { Male, } \\
\text { lower } \\
\text { second- } \\
\text { ary edu- } \\
\text { cation }\end{array}$ & $\begin{array}{c}\text { Male, } \\
\text { upper } \\
\text { second- } \\
\text { ary edu- } \\
\text { cation }\end{array}$ & $\begin{array}{c}\text { Male, } \\
\text { univer- } \\
\text { sity edu- } \\
\text { cation }\end{array}$ & $\begin{array}{c}\text { Female } \\
\text { primary } \\
\text { educa- } \\
\text { tion }\end{array}$ & $\begin{array}{c}\text { Female, } \\
\text { lower } \\
\text { second- } \\
\text { ary edu- } \\
\text { cation }\end{array}$ & $\begin{array}{c}\text { Female, } \\
\text { upper } \\
\text { second- } \\
\text { ary edu- } \\
\text { cation }\end{array}$ & $\begin{array}{c}\text { Female, } \\
\text { higher } \\
\text { educa- } \\
\text { tion }\end{array}$ \\
\hline $\begin{array}{l}\text { Female, } \\
\text { upper } \\
\text { secondary } \\
\text { education }\end{array}$ & 0.000 & 0.000 & 0.000 & 0.000 & 0.000 & 0.000 & & 0.000 \\
\hline $\begin{array}{l}\text { Female, } \\
\text { higher } \\
\text { education }\end{array}$ & 0.009 & 0.000 & 0.000 & 0.950 & 0.056 & 0.046 & 0.000 & \\
\hline
\end{tabular}

Note: Significantly important values are highlighted in italic.

Based on Tukey's HSD test results (Table 11), for motivating factor of a good working team we can conclude that there are significant differences in results concerning women with secondary education with and without GCE, female university graduates and the results of other groups of employees. Different perceptions can only be seen in the relationships between women with primary school education and men with university education. The finding confirms WH4. This motivation factor is statistically more significant for women than for men. Women are based on good relationships more than men. Working relationships are very important especially for women with higher education.

\subsection{Motivation factor: job security}

A permanent job provides the source of income necessary for life. It is also important to have job security for various age categories. Job security plays different roles for young people and for family providers. People afraid of possible losing of their jobs often accept lower wages and worse working conditions. We noted that $86.79 \%$ of the respondents evaluated the motivation factor job security as "very important" and "important" (Table 12).

Table 12. Relative frequency for motivational factor job security from the point of view of education

\begin{tabular}{|l|c|c|c|c|c|c|}
\hline \multirow{2}{*}{ Education } & \multicolumn{5}{|c|}{ Values of importance } & \multirow{2}{*}{ Total } \\
\cline { 2 - 6 } & 1 & 2 & 3 & 4 & 5 & \\
\hline \multirow{2}{*}{$\begin{array}{l}\text { Primary } \\
\text { school }\end{array}$} & 12 & 32 & 104 & 230 & 311 & 689 \\
\hline & $1.74 \%$ & $4.64 \%$ & $15.09 \%$ & $33.38 \%$ & $45.14 \%$ & $100 \%$ \\
\hline $\begin{array}{l}\text { Lower } \\
\text { secondary } \\
\text { education }\end{array}$ & 60 & 167 & 520 & 1,579 & 2,158 & 4,484 \\
\cline { 2 - 6 } & $1.34 \%$ & $3.72 \%$ & $11.60 \%$ & $35.21 \%$ & $48.13 \%$ & $100 \%$ \\
\hline $\begin{array}{l}\text { Upper } \\
\text { secondary } \\
\text { education }\end{array}$ & 110 & 291 & 1,413 & 5,212 & 7,303 & 14,329 \\
\hline $\begin{array}{l}\text { Higher } \\
\text { education }\end{array}$ & $0.77 \%$ & $2.03 \%$ & $9.85 \%$ & $36.38 \%$ & $50.97 \%$ & $100 \%$ \\
\cline { 2 - 6 } & 46 & 119 & 615 & 2,633 & 3,501 & 6,914 \\
\hline Total & 150 & 481 & 2,175 & 9,285 & 14,325 & 26,416 \\
\hline
\end{tabular}


Table 13. $\chi^{2}$ test for motivational factor job security from the point of view of education

\begin{tabular}{|l|c|c|c|}
\hline & Chi-square & Degree of freedom & $\mathrm{p}$-level \\
\hline Pearson's chi-square & 167.88 & $\mathrm{df}=12$ & $\mathrm{p}=0.000$ \\
\hline M-V chi-square & 155.10 & $\mathrm{df}=12$ & $\mathrm{p}=0.000$ \\
\hline
\end{tabular}

Based on the results relative frequency for motivational factor job security (Table 14) and on the results of Pearson's chi-quadrate test, we can confirm (Table 13) that the level of education and the motivation factor: job security is interdependent (p-level $<0.05$ ). We thus confirm WH1 for motivation factor job security.

Table 14. Relative frequency for motivational factor job security from the point of view of gender

\begin{tabular}{|l|c|c|c|c|c|c|}
\hline \multirow{3}{*}{ Gender } & \multicolumn{5}{|c|}{ Values of importance } & \multirow{2}{*}{ Total } \\
\cline { 2 - 6 } & 1 & 2 & 3 & 4 & 5 & \\
\hline \multirow{2}{*}{ Male } & 122 & 304 & 1,476 & 4,251 & 7,510 & 13,663 \\
\cline { 2 - 6 } & $0.89 \%$ & $2.22 \%$ & $10.80 \%$ & $31.11 \%$ & $54.97 \%$ & $100 \%$ \\
\hline \multirow{2}{*}{ Female } & 102 & 250 & 1,199 & 3,736 & 7,466 & 12,753 \\
\cline { 2 - 6 } & $0.80 \%$ & $1.96 \%$ & $9.40 \%$ & $29.30 \%$ & $58.54 \%$ & $100 \%$ \\
\hline Total & 224 & 554 & 2,675 & 7,987 & 14,976 & 26,416 \\
\hline
\end{tabular}

Based on Pearson's chi-quadrate test, we can state (Table 15) that gender and motivation factor job security are interdependent ( $\mathrm{p}$-level < 0.05). We thus confirm WH2 for motivation factor job security.

Table 15. $\chi^{2}$ test for motivational factor job security from the point of view of gender

\begin{tabular}{|l|c|c|c|}
\hline & Chi-square & Degree of freedom & $\mathrm{p}$-level \\
\hline Pearson's chi-square & 37.70 & $\mathrm{df}=4$ & $\mathrm{p}=0.000$ \\
\hline M-V chi-square & 37.74 & $\mathrm{df}=4$ & $\mathrm{p}=0.000$ \\
\hline
\end{tabular}

Based on Tukey's HSD test (Table 16) for the motivation factor of job security we can conclude that, in terms of gender and education, significant differences have been detected at a $5 \%$ level of significance among all male education-level groups and female education-level groups, with the only exception being female university graduates correlated to men with primary education, high school with and without GCSE and female high school graduates without GCSE and men with high school education without GCSE. Based on the findings, WH5 was confirmed partially. The high importance of job security for women can be given by the current high number of women who are family-breeders, for various reasons. Women with university education are an exception. Their self-confidence in the subsequent early employment following the possible loss of employment can be the reason. 
Table 16. Tukey's HSD test results within motivational factors for job security

\begin{tabular}{|c|c|c|c|c|c|c|c|c|}
\hline $\begin{array}{l}\text { Gender/ } \\
\text { Education }\end{array}$ & $\begin{array}{l}\text { Male } \\
\text { pri- } \\
\text { mary } \\
\text { educa- } \\
\text { tion }\end{array}$ & $\begin{array}{l}\text { Male, } \\
\text { lower } \\
\text { second- } \\
\text { ary edu- } \\
\text { cation }\end{array}$ & $\begin{array}{l}\text { Male, } \\
\text { upper } \\
\text { second- } \\
\text { ary edu- } \\
\text { cation }\end{array}$ & $\begin{array}{l}\text { Male, } \\
\text { univer- } \\
\text { sity edu- } \\
\text { cation }\end{array}$ & $\begin{array}{c}\text { Female } \\
\text { primary } \\
\text { educa- } \\
\text { tion }\end{array}$ & $\begin{array}{l}\text { Female, } \\
\text { lower } \\
\text { second- } \\
\text { ary edu- } \\
\text { cation }\end{array}$ & $\begin{array}{l}\text { Female, } \\
\text { upper } \\
\text { second- } \\
\text { ary edu- } \\
\text { cation }\end{array}$ & $\begin{array}{c}\text { Female, } \\
\text { higher } \\
\text { educa- } \\
\text { tion }\end{array}$ \\
\hline $\begin{array}{l}\text { Male } \\
\text { primary } \\
\text { education }\end{array}$ & & 0.000 & 0.005 & 0.000 & 0.000 & 0.020 & 0.000 & 0.155 \\
\hline $\begin{array}{l}\text { Male, lower } \\
\text { secondary } \\
\text { education }\end{array}$ & 0.000 & & 0.006 & 0.012 & 0.000 & 0.219 & 0.000 & 0.094 \\
\hline $\begin{array}{l}\text { Male, } \\
\text { upper } \\
\text { secondary } \\
\text { education }\end{array}$ & 0.005 & 0.006 & & 0.000 & 0.000 & 0.000 & 0.000 & 0.156 \\
\hline $\begin{array}{l}\text { Male, } \\
\text { university } \\
\text { education }\end{array}$ & 0.000 & 0.012 & 0.000 & & 0.000 & 0.000 & 0.000 & 0.000 \\
\hline $\begin{array}{l}\text { Female } \\
\text { primary } \\
\text { education }\end{array}$ & 0.000 & 0.000 & 0.000 & 0.000 & & 0.000 & 0.000 & 0.000 \\
\hline $\begin{array}{l}\text { Female, } \\
\text { lower } \\
\text { secondary } \\
\text { education }\end{array}$ & 0.020 & 0.219 & 0.000 & 0.000 & 0.000 & & 0.099 & 0.002 \\
\hline $\begin{array}{l}\text { Female, } \\
\text { upper } \\
\text { secondary } \\
\text { education }\end{array}$ & 0.000 & 0.000 & 0.000 & 0.000 & 0.000 & 0.099 & & 0.000 \\
\hline $\begin{array}{l}\text { Female, } \\
\text { higher } \\
\text { education }\end{array}$ & 0.155 & 0.094 & 0.156 & 0.000 & 0.000 & 0.002 & 0.000 & \\
\hline
\end{tabular}

Note: Significantly important values are highlighted in italic.

\section{Discussion}

The main objective of presented research was focused on the analysis of the impact of education on the level of employee motivation and also on the confirmation of gender-based differences in motivation between men and women. We assumed that people with various levels of education may have different motivation needs. At the same time, we assumed that differences in motivation may also occur between men and women. To verify statistical dependence or independence between the level of education achieved, respondents' gender and a selected motivation factor, Pearson $\chi^{2}$ good match test and Tukey's HSD test were used.

We also predicted differences between men and women in terms of motivation. By comparing gender-based employment relationships, we proved that women are more oriented to work relationships than men. Many scholars attribute this fact to cultural factors. They argue 
that there are prejudices towards women at the workplace, and that is what makes them more assertive and increases their effort to compete in the workplace. We have also come to the conclusion that women consider a good working team to be more important than men do.

This is also the case for the motivation factor of basic salary, where men have expressed a neutral attitude whereas women considered this factor very important. With the job security factor, the situation is similar, with the difference that men assign it important level and women consider it very important. At the same time, we assumed that there are gender differences in terms of motivation. Our research confirmed these differences and also confirmed the existence of gender dependence and motivational factors.

Our findings confirm that women ascribe more importance to the studied motivational factors than men. We presume that the causes of different views between various sexes and specific motivational factors are due to the fact that women are more oriented toward social security. They care about working relationships, they mostly concern themselves with who thinks what about them, they learn to cooperate, adapt and make compromises in order to maintain good relationships.

Therefore, they demand more of the working atmosphere, for example, and require good working relationships with colleagues and senior staff. Men, on the other hand, have higher expectations and self-confidence. However, men also care about base salary and job security.

The issue of motivation was already discussed by Nguyen et al. (2014). In their study, focused on Dutch respondents, they found out that Dutch employees with higher education were more motivated in relation to workplace relationships than those who had not obtained a secondary education. Freund's research (2006) confirmed that educated employees are most motivated by success and the effort to improve their own performance.

With regard to university-educated employees, our results, similar to those reported by Lorincová et al. (2016), confirmed that a good working team and job security are very important to such people, whereas the basic salary is only an important motivating factor. Peterson's research (2004) confirmed that both men and women appreciate when working relationships are satisfactory in the workplace, when they have the opportunity to grow and develop and when they receive recognition and respect for the work they have achieved.

In addition, women prefer a good working team whereas men more depend on the superior's approach. The results of this study show that an orientation toward workplace relations is the predominant style of leadership in the Netherlands. On the other hand, ArnaniaKepuladze's (2010) research does not match our results.

The author has not found a direct relationship between gender and motivation. On the other hand, according to Meece et al. (2006), women need to fulfil needs such as family and the quality of their family life. Based on this statement, the authors of this research presume that the most important ways of motivating women are interpersonal relationships, security, social benefits, working environment, and the like.

Inceoglu et al. (2012) say that differences between the sexes can be observed in relation to changes in life. For example, when women have a need to establish a family, their priorities may change. Hofstede (2001) concludes that the differences in male motivation consist mostly of income, promotion, and responsibility. Women appreciate the friendly atmosphere, prestige, challenge, importance of work, job security and mutual cooperation. Tohidi and 
Jabbari (2012) found that men usually put the emphasis on salary, whereas the women prefer professional development.

\section{Conclusions}

We conclude that both of our working hypotheses for the most important motivational factors have been confirmed. Our study has determined that, in Slovakia, gender and education significantly affect the level of motivation. Based on our results, we can state the following conclusions.

Men with basic education and men with higher education are motivated by the basic salary significantly more than women of any education level. At the same time, there are significant differences between women with secondary education without GCSE (lower secondary education), women with secondary education with GCSE (upper secondary education) and women with higher education compared to other groups of employees. Different perceptions can be seen only in the relationships between women with primary school and men with university education.

As for the motivation factor of a good working team, we determined that, with regard to gender and education, there are significant differences between women with secondary education without GCSE, women with secondary education with GCSE and women with higher education compared to other groups of employees. Different perceptions can be seen only in the relationships between women with primary school education and men with university education.

As for the motivation factor of job security, we noticed significant differences between all male education groups and women's education groups, except for the group of women with university education, males with elementary school education, secondary schools with and without GCSE and men without secondary education.

Employees are the most important factor in every business. Therefore, due attention must be paid to them. A satisfied employee values their job as well as their manager. They try to perform work at a high or above-average quality; a precondition for such high performance is, however, motivation.

Recognizing of employee motivation needs is a key factor in keeping an employee in the organization. In the current economic situation in Slovakia, when the unemployment rate is at the historical minimum, loyal non-inflating employees presents a competitive advantage at labour market. Our findings from the point of view of scientific benefits, as well as their practical use, enable business managers to target the motivation program on their employees according to their motivation needs. It is possible to specified by gender and education. There exist other possibilities of specializing motivation programs, according to the job position, seniority or age. Nevertheless, specialized motivation program can be a costly item, its effect is reflected in employee satisfaction. Satisfied employee can provide qualitatively high performance in the long run, so financial benefits can be highly profitable to the organization.

The diversity and specificity of the motivation needs of employees are the limitation of our research. This limitation can be eliminated by similarly motivated groups of employees that can be defined by cluster analysis. At present, financial and material stimulus factors 
are main motivation factors used by managers in Slovakia. Our research has shown that employees are interested in other motivation factors, too. Therefore, our recommendation for personal managers is to start using other motivation factors. At the same time, it is necessary to differentiate the creation of motivation programmes according to education and by gender focusing on similarly motivated groups of employees. This may increase the effectiveness of motivation programme and it can help to intensify satisfaction of employees at work, more effectively meet company's business goals, and increase competitiveness in the market.

\section{Acknowledgement}

The research was supported by VEGA project No. 1/0024/17, VEGA project No. 1/0320/17, VEGA project No. 1/0348/17 and APVV-16-0297.

\section{References}

Arnania-Kepuladze, T. 2010. Gender stereotypes and gender feature of job motivation: differences or similarity? Problems and Perspectives in Management 8(2): 84-93.

Buttner, E. 1993. Female entepreneurs: How far have they come?, Business Horizons 36(March-April): 59-65. https://doi.org/10.1016/S0007-6813(05)80039-4

Chromjaková, F. 2016. The key principles of process manager motivation in production and administration processes in an industrial enterprise, Journal of Competitiveness 8(1): 95-110. https://doi.org/10.7441/joc.2016.01.07

DeMartino, R.; Barbato, R. 2003. Differences between women and men MBA entrepreneurs: exploring family flexibility and wealth creation as career motivators, Journal of Business Venturing 18(6): 815-832. https://doi.org/10.1016/S0883-9026(03)00003-X

Eskildsen, J. K.; Nussler, M. L. 2003. The managerial drivers of employee satisfaction and loyalty, Total Quality Management 11(4-6): 581-588.

Fila, M.; Schwarczová, L.; Mura, L. 2015. Citizen satisfaction survey as a tool of citizen relationship management of local government in Slovakia, Serbian Journal of Management 10(1): 117-129. https://doi.org/10.5937/sjm10-7147

Freund, A. M. 2006. Age-differential motivational consequences of optimization versus compensation focus in younger and older adults, Psychology and Aging 21(2): 240-252. https://doi.org/10.1037/0882-7974.21.2.240

Hitka, M.; Balážová, Ž. 2015. The impact of age, education and seniority on motivation of employees, Business: Theory and Practice 16(1): 113-120. https://doi.org/10.3846/btp.2015.433

Hitka, M.; Hajduková, A.; Balážová, Ž. 2014. Impact of the economic crisis on the change in motivation of employees of woodworking industry enterprise, Drvna industrija 65(1): 21-26. https://doi.org/10.5552/drind.2014.1303

Hofstede, G. 2001. Culture's consequences: comparing values, behaviors, institutions, and organizations across nations, Journal of Marketing 67(2): 151-153.

Inceoglu, I.; Segers, J.; Bartram, D. 2012. Age-related differences in work motivation, Journal of Occupational and Organizational Psychology 85(2): 300-329. https://doi.org/10.1111/j.2044-8325.2011.02035.x

Irum, S.; Sultana, A.; Ahmed, K.; Mehmood, N. 2012. Work motivation differences in public and private sector (A study of higher education institutes in Pakistan), Interdisciplinary Journal of Contemporary Research in Business 4(6): 685-699. 
Kampf, R.; Ližbetinová, L. 2015. The identification and development of talents in the environment of logistics companies, Naše more 62(3): 139-142. https://doi.org/10.17818/NM/2015/SI9

Kanfer, R.; Ackerman, P. L. 2004. Aging, adult development, and work motivation, The Academy of Management Review 29(3): 440-458.

Lorincová, S.; Schmidtová, J.; Javorčíková, J. 2016. Employee job satisfaction in furniture manufacturing companies in the Slovak Republic, Drvna Industrija 67(4): 351-362. https://doi.org/10.5552/drind.2016.1614

Lussier, R. N.; Achua Ch. F. 2013. Leadership: theory, application, and skill development. $5^{\text {th }}$ ed. SouthWestern: Erin Joyner.

Meece, J. L.; Glienke, B. B.; Burg, S. 2006. Gender and motivation, Journal of School Psychology 44(5): 351-373. https://doi.org/10.1016/j.jsp.2006.04.004

Milne, P. 2007. Motivation, incentives and organisational culture, Journal of Knowledge Management 11(6): 28-38. https://doi.org/10.1108/13673270710832145

Moran, A.; Kilpatrick, R.; Abbott, L.; Dallat, J.; McClune, B. 2001. Training to teach: motivating factors and implications for recruitment, Evaluation and Research in Education 15(1): 17-32. https://doi.org/10.1080/09500790108666980

Nadeem, M.; Rana, M. S.; Lone, A. H.; Maqbool, S.; Naz, K.; Ali, A. 2011. Teacher's competencies and factors affecting the performance of female teachers in Bahawalpur (Southern Punjab) Pakistan, International Journal of Business and Social Science 2(19): 217-222.

Nguyen, L. D.; Mujtaba, B. G.; Ruijs, A. 2014. Stress, task, and relationship orientations of Dutch: do age, gender, education, and government work experience make a difference?, Public Organization Review 14(3): 305-324. https://doi.org/10.1007/s11115-013-0222-2

Pacáková, V. a kol. 2009. Štatistické metódy pre ekonómov. Bratislava: Iura Editon.

Peterson, M. 2004. What men and women value at work: implications for workplace health, Gender Medicine 1(2): 106-124. https://doi.org/10.1016/S1550-8579(04)80016-0

Ryan, R. M.; Deci, E. L. 2000. Intrinsic and extrinsic motivations: classic definitions and new directions, Contemporary Educational Psychology 25(1): 54-67. https://doi.org/10.1006/ceps.1999.1020

Schmidtová, J.; Vacek, V. 2013. Applied statistics. Zvolen: Technická univerzita vo Zvolene.

Stachová, K.; Stacho, Z.; Pajtinková Bartaková, G. 2015. Influencing organisational culture by means of employee remuneration, Business: Theory and Practice 16(3): 264-270. https://doi.org/10.3846/btp.2015.492

StatSoft, Inc. 2013. STATISTICA. Data analysis software system, version 12. Available from Internet: www.statsoft.com

Sumita, R. 2014. Motivational theories and incentives approaches, Indian Institute of Management Bangalore Management Review 16(4): 43-50.

Tohidi, H.; Jabbari, M. M. 2012. The effects of motivation in education, Procedia - Social and Behavioral Sciences 31: 820-824. https://doi.org/10.1016/j.sbspro.2011.12.148

Urbancová, H. 2013. Competitive advantage achievement through innovation and knowledge, Journal of Competitiveness 5(1): 82-96. https://doi.org/10.7441/joc.2013.01.06

Warr, P.; Birdi, K. 1998. Employee age and voluntary development activity, International Journal of Training and Development 2(3): 190-204. https://doi.org/10.1111/1468-2419.00047 